\title{
TRADUCCIÓN DE TRES POEMAS EN PROSA DE Aloysius Bertrand
}

\author{
Nathaly Bernal Sandoval
}

Presento mi traducción de tres poemas de Aloysius Bertrand, publicados dentro de Gaspard de la nuit, fantaisies à la manière de Rembrandt et de Callot ${ }^{2}$, la suma de sus poemas en prosa, que fue publicada de manera póstuma en $1842^{3}$. El poemario, que le ha ganado a Bertrand -aunque no de manera muy extendida- la fama de haber fundado el género de la poesía en prosa, está dividido en seis libros y una sección más llamada Piezas sueltas (Pièces détachées). Los poemas que presento se titulan en el original Ondine (Ix, tercer libro: La noche y sus prestigios), Le gibet y Scarbo (XI y XII, Piezas sueltas).

La elección, si bien parece responder al azar o a un gusto propio, se basa en un descubrimiento afortunado que hice poco después de leer a Bertrand por primera vez. Se trata de la composición para piano de Maurice Ravel, escrita en 1908 para que el pianista español Ricardo Viñes la ejecutara el siguiente año. Esta obra se titula Gaspard de la nuit: trois poèmes pour piano d'après Aloysius Bertrand 4 , y está dividida en tres movimientos, que corresponden a los poemas ya mencionados. Ravel realiza una maravillosa traducción intersemiótica ${ }^{5}$, de un poema a una partitura, y en los movimientos logra evocar y transmitir la sutilidad y el onirismo de un encuentro con una criatura fantástica; la

\footnotetext{
${ }^{1}$ Nathaly Bernal Sandoval es licenciada en Inglés, de la Universidad Industrial de Santander y becaria de la Maestría en Traducción, de El Colegio de México. Traduce del inglés y del francés. Dentro de sus intereses se cuentan la traducción literaria y la crítica de traducciones. Actualmente realiza su tesis sobre la traducción de ensayo, a partir de la obra de Virginia Woolf, y prepara un libro con la traducción de dos ensayos epistolares de la misma autora. Correo electrónico: nbernal@colmex.mx

${ }^{2}$ Siglind Bruhn comenta que el nombre Gaspard, de origen persa, se refiere a aquel que cuida un tesoro, y sugiere una posible traducción del título al inglés, idea que me gustaría traducir, a mi vez, al español, como Centinela de la noche. Fantasías a la manera de Rembrandt y de Callot (1997: xxviii).

${ }^{3}$ La edición de la cual se toman los poemas originales fue editada en 1925 por Payot.

${ }^{4}$ Centinela de la noche: tres poemas para piano a partir de Aloysius Bertrand (traducción propia).

${ }^{5}$ Aquella en la que las palabras se interpretan por medio de sistemas no verbales. Al respecto, véase Roman Jakobson, On linguistic aspects of translation (2004).
} 
expectación y el sobresalto que produciría la observación de una horca; y la agilidad y la facilidad para escabullirse de un duende.

Aunque Bertrand ha sido traducido en varias ocasiones -es posible encontrar traducciones de poemas o de secciones dentro de otros libros o sitios en internet-, la mayoría de ellas no conforman ediciones independientes en sí mismas. Es quizás debido a esto que Bertrand no hace parte de las lecturas en los cursos de poesía, ni en los de literatura francesa, y por lo que además pensamos en otros autores como Baudelaire o Rimbaud cuando hablamos sobre el poema en prosa. Permítaseme mencionar El spleen de París o Una temporada en el infierno como ejemplos que sí vienen a la mente en estos casos y que sí están en bibliotecas y planes de estudio. Vale la pena, sin embargo, recordar que Bertrand es de las influencias más notorias en la pluma de Baudelaire, no solo en cuanto a temas -la vida cotidiana y los objetos corrientes-, sino en el tratamiento y en la forma.

La muestra de poemas que he elegido también sirve para dar cuenta de esta relación. Así como Bertrand escribe sobre ondinas, estas ninfas del agua protagonistas de muchas leyendas e historias tradicionales, Baudelaire también escribe sobre criaturas fabulosas, hadas y ángeles. En ambos escritores está presente la exaltación de las emociones indignas, de las cosas terrestres y de las pasiones vulgares, aunque el segundo se haya encaminado, de manera decidida, a referir apreciaciones urbanas, su forma de sentir París.

Pero pasemos ahora de mis propias apreciaciones a los poemas de Bertrand

\section{Ondina}

Me parecía oír

que una vaga armonía encantaba mi sueño.

$Y$ cerca a mí se dispersaba un rumor idéntico

a los cantos entrecortados de una voz triste y tierna.

Ch. Brugnot - Los dos genios 
«— ¡Escucha!, ¡escucha! - Soy yo, Ondina, la que roza con gotas de agua los rombos azules de tu ventana, iluminados por los lúgubres rayos de la luna. He aquí, con un vestido irisado, la dama del castillo que contempla desde su balcón la bella noche estrellada y el bello lago que duerme.

«Cada raudal es un espíritu del agua que nada con la corriente, cada corriente es un sendero que serpentea hacia mi palacio, y mi palacio es un entramado líquido, anclado dentro del triángulo que forman el fuego, la tierra y el aire en el fondo del lago.

«- ¡Escucha!, ¡ ¡scucha!- - Es mi padre quien golpea con una rama de aliso verde las aguas que rugen, y son mis hermanas quienes acarician con sus manos de espuma las frescas islas de hierbas, de nenúfares y de gladiolos, o se burlan del sauce decrépito y lanudo que sostiene una caña de pescar».

Una vez que murmuró su canción, me rogó que recibiera en mi dedo su anillo, para que me convirtiera en el esposo de una ondina, para que visitara con ella su palacio, para que fuera el rey de los lagos.

Y como le respondí que amaba ya a una mortal, malhumorada y rencorosa, vertió algunas lágrimas, luego soltó una carcajada y se desvaneció en una tormenta que se derramó en gotas blancas a lo largo de mis vitrales azules.

\section{La horca}

¿Qué es lo que veo mecerse alrededor de esa horca?

Fausto

¡Ah! Eso que oigo ¿será el aullido del cierzo nocturno, o el suspiro que exhala el ahorcado en la columna del patíbulo?

¿Será algún grillo que canta agazapado entre el musgo y la hiedra estéril, donde el bosque, por piedad, se calza?

¿Será alguna mosca que toca el corno de caza, en el fragor del toque final, en los oídos sordos?

¿Será algún escarabajo que en su vuelo irregular arranca de un cráneo un cabello ensangrentado? 
¿O será acaso alguna araña que teje una cinta de seda que sirva de corbata a este cuello estrangulado?

Es la campana que tañe en los muros de una ciudad, bajo el horizonte, y los despojos de un ahorcado los que tiñen de rojo el sol que se pone.

Scarbo

Él mira debajo de la cama, en la chimenea, dentro del baúl: no hay nadie. No puede comprender por dónde ha entrado, o por dónde se ha escapado.

Hoffmann - Nocturnos

¡Ay! ¡Cuántas veces he visto y oído a Scarbo, cuando a medianoche la luna brilla en el cielo como un escudo de plata sobre una bandera de azur, henchida de abejas de oro!

¡Cuántas veces he oído que su risa resuena en las sombras de mi habitación, y sus uñas rechinan en el dosel de seda de mi cama!

¡Cuántas veces lo he visto caer al suelo, brincar en un solo pie y rodar por el cuarto como las chispas que emanan de la varita de un hechicero!

¿Lo creí desaparecido? El enano crecía entre la luna y yo, como el tañido de una catedral gótica, como el vaivén de un cascabel de oro en un sombrero puntiagudo.

Pero tan pronto su cuerpo se azulaba, su rostro, a su vez, se tornaba pálido, diáfanos los dos como la cera de un cirio. Y de repente se extinguía.

\section{Referencias}

Bertrand, Aloysius. Gaspard de la nuit : fantaisies à la manière de Rembrandt et de Callot. París: Payot, 1925.Impreso.

Bruhn, Siglind. Images and ideas in modern French piano music: the extramusical subtext in piano works by Ravel, Debussy, and Messiaen. Vol. 6. Nueva York: Pendragon Press, 1997.Impreso. 